\section{THE TEACHING UNIVERSITY.}

$\mathrm{A}^{\mathrm{T}} \mathrm{t}$ the enstuing meeting of Convocation of the University of London (on April Io next), the rejection of the Gresham Commission scheme will be the subject of the first motion. It is intended (if possible) to propose an amendment which will, in effect, be a declaration that Convocation generally approves of the scheme as enabling the University to make extended provision for teaching, and for the advancement of learning, and for original research in London in accordance with, and in furtherance of, the principles already sanctioned by the several charters of the University. The following special, among other reasons, in general support of the Gresham Commission proposals, are now submitted to the consideration of your readers and the members of Convocation interested in the welfare of their University :--

(I) The original London University was intended to be both a teaching and a degree-conferring body.

(2) The University of the "3o's" was open to collegiate candidates only, and was governed by a strictly professorial body, consisting of the examiners, who formed the senate of the University.

(3) Under the charter of 1858 the non-collegiate student was admitted to the examinations, but the older system has never been abolished, nor has the principle thereof ever been abrogated.

(4) In the existing charter (Sec. 2) the object is declared to be "to hold forth . . . an encouragement for pursuing a liberal and regular course of education."

In Sec. 34 a long list of affiliated colleges is given, in the neyt section power is conferred to "alter, vary, and amend" such list, and in Sec. 36 non-collegiate students are made admissible (except in medicine) "on such conditions" as the Senate may prescribe.

(5) Under Sections 18-38, and following, the Senate is empowered to examine for, and confer degrees on such conditions as it may think fit (subject to general law and the charter) to confer ad eundem degrees, and grant certificates of proficiency.

(6) It is, therefore, clear that the University is still essentially what it was originally--a collegiate University, with the added faculty of admitting non-collegiate students "upon conditions." The chief fault found with the collegiate system in 1858 was, in effect, that it was imperfectly established and insufficiently administered. It could have been reformed, and its maintenance was supported by $53 \mathrm{I}$ graduates against 38 who advocated the admission of the non-collegiate, as well as of the collegiate, student.

(7) It is equally clear that nothing in the existing charters prevents the University from establishing special examinations (if need be, which is very doubtful) for collegiate and non-collegiate students respectively, Professorships, Boards of Studies, Faculties, and even (probably) an Academic Council or its equivalent, such as provided by the Gresham Commission scheme, which, running counter to no principle sanctioned by any former or by the present charters, mainly restores and extends the University, methodises and regulates its educational machinery, and enables it to exercise such direct control over teaching as any well-wisher to academical education must surely desire to see it endowed with.

(8) The non-collegiate student, in whose favour alone does the Gresham scheme depart from the original principle of the University, cannot but gain by having his studies directed by the whole teaching force of the metropolis. At present only two professors actually engaged in teaching, representing only one out of the numerous subjects comprised within the faculties of Art, Science, Medicine, and Laws (exclusive of clinical medicine, NO. I 275 , VOL. 49] which is well represented), sit upon the councils of the University. Even Convocation, during its whole existence, appears to have elected only two professors. Such a divorce of testing from teaching has been long regretted by most teachers of eminence, metropolitan or provincial, and by most, if not all, of the Examiners of the University.

(9) Lastly, as measuring the comparative academical success of collegiate and non-collegiate courses of study, the figures which I give in a note are not uninstructive ${ }^{1}$ :-

If conclusions may be drawn from these figures, the academical success of the graduates who were largely non-collegiate, would appear to be one-half of that of the graduates who were largely collegiate, and one-fourth of that of the graduates who have always been wholly collegiate.

(ro) As collegiate and non-collegiate candidates are certainly of equal intrinsic quality, it would seem that the difference is to be ascribed to the superiority of collegiate over non-collegiate courses of study.

(I I) Hence the collegiate principle, the original principle of the University, which it has never abrogated, would appear to be the principle most likely to repay extension-and this is precisely what the Gresham Commission scheme proposes to do-and there is nothing to show that its extension need in the slightest degree interfere with the interests of the non-collegiate student. On the contrary, it would facilitate the increase of his opportunities for regular irstruction of the highest character.

(12) In conclusion, the assumption underlying the foregoing remarks is that the chief object of a University is the advancement of learning and research, and not the mere granting of degrees. which are but a means to an end. The eloquent appeal of Lord Reay, appended to the Gresham Report, should be carefully studied by all interested in the University questions.

\section{F. VICTOR DICKINS}

\section{WILLIAM PENGELLY}

THE death of William Pengelly, at the ripe age of eighty-two, deserves more than a passing notice, because he was one of the last survivors of a scientific type represented by Sedgwick, Lyell, Phillips, Murchison, and the other old heroes who laid the foundation of geological science. He belongs to the heroic age of geology - to that group of men who found British Geology almost a terra incognita, and left it so completely explored that there is little left for their successors but to correct mistakes and fill in minute details.

Pengelly was born in 1812 , at East Looe, in Cornwall, of a Quaker stock, and lived all his life in the west country. Like Prof. Dana, he took to the sea and served before the mast. Having, however, a decided taste for mathematics and geology, he gave up seafaring and

1 During the last five years the annual number of B.A.'s (largely non collegiate) has sunk from 238 in 1889 , to 156 in 1893 , a diminution of 34 per cent. From 1858 to 1893 , the annual number of B.A.'s has increased from 70 to 156 , of B.Sc.'s from 5 to 80 (in 1892 - for some reason or other-the number dwindled to 6 in 1893 ), of M.B.'s from 20 to 89 , and of M.D.'s from r 6 to 59

[The science candidates are mainly collegiate, the medical candidates have always been wholly collegiate.]

During the last three years, $189 \times-2-3$

Of 639 B.A.'s, 38 took Ist Class Honours, about 5 per cent.

Uf 250 B.Sc.'s, 28 ", ", ", rr ,$$
\text { Of } 249 \text { M.E.'s, } 55 \text { " " " " } 22 \text {," }
$$

Of some 500 graduates in Honours at the B.Sc. examination (since the institution of the degree in I85r to 1892 ), 470 were collegiate students, and only 30 were non-collegiate.

During the same period, of some ro 80 B.A. Honours men, only 260 were wholly non-collegiate, the remainder, 720 , were collegiate students. O the 260 non-collegiates, 42 obtained a rst Class in Honours, chiefly in modern languages; the remaining 218 were largely placed in the 3 rd Class. 
settled down as a teacher in Torquay. Here for some sixty years he threw himself into the work of higher education, and more especially in the direction of natural science. In 1837 , through his energy, the Torquay Mechanics Institute, which had fallen on evil days, was reorganised and put on a satisfactory working basis. Seven years later he founded the Torquay Natural History Society, and in 1863 he extended the range of his personal influence by establishing the Devonshire Association that took root and flourished exceedingly, and has been of great service in the West of England. It is impossible to read any one of the many volumes published by the Association without realising how great has been his influence in bringing natural knowledge within reach of the people. The museum at Torquay is also an enduring monument to his energy, which will continue to teach when his name is forgotten.

Pengelly was, however, beyond all other things, a geologist, devoted to the study of Devonshire. The collection of Devonian fossils in the Oxford Museum is spoil of his hammer. He collected also the materials for the "Monograph on the Lignite Formation of Bovey Tracey," a joint publication with Dr. Heer, that has thrown so much light on the Miocene forests which clothed the slopes around the Lake of Bovey. During the second quarter of the present century, the question of the antiquity of man was steadily coming to the front. In 1847 Boucher de Perthes published his discovery of flint implements along with the extinct mammalia in the rivergravels of Amiens and Abbeville. Similar discoveries in Kent's Hole by Mr. M'Enery, made some time between 1825 and 1839 , had been verified by Godwin-Austen in I840, and the Torquay Natural History Society in 1846 . So strong, however, were the prejudices against the antiquity of man, that the matter was not thought worthy of further investigation, until the year i 858 . Then it was determined that a new cave at Brixham, near Torquay, should be explored by a joint committee of the Royal and Geological Societies, consisting, among others, of Lyell, Falconer, Ramsay, Prestwich, Owen, and GodwinAusten, with Pengelly as the superintendent of the work. The result of the exploration established beyond all doubt the existence of palæolithic man in the Pleistocene age, and caused the whole of the scientific world to awake to the fact of the vast antiquity of the human race. From this time Pengelly's energies were mainly directed towards cave exploration. In 1865 he undertook the superintendence of the exploration of Kent's Hole by a committee of the British Association. It was at this time that I first became associated with him in cavedigging, and as we came to know one another, I learnt to admire his method, and his patient and accurate work. Day by day, excepting when the work was stopped, he visited the cave and recorded on maps and plans the exact spot where each specimen was found, for no less than sixteen years. The vast collection of palæolithic implements and fossil bones, each of which bears traces of his handiwork, is represented in most of the museums in this country, and the annual reports, listened to with so much pleasure by crowds at the meetings of the British Association, are the most complete that have ever been published. It may be objected that the accumulation of so much evidence of the existence of man in the Pleistocene age, in the south of England, was unnecessary. It was, however, necessary to sweep away the mass of prejudice, and this could best be done by repeating the evidence. Had this not been done, early man would not occupy the recognised position which he now holds in the annals of geology. The rest of Pengelly's life was mainly given up to the researches in other caves in Devonshire. In estimating his scientific work, it must not be forgotten that it was done in addition to the daily task of bread-winning.
There remains one other side of Pengelly's many-sided character which deserves remark. He was a fluent and genial speaker and lecturer. For many years he was a leading figure at the meetings of the British Association, and there are but few large centres where he was not known as a lecturer and not welcomed as a friend. Some of his jeux d'esprit, such as, for example, his saying in treating of the thorny question of man's antiquity, "that you may be as naughty as you like," will long be remembered. He has died full of years, and with his services honourably recognised by his private friends and by the scientific world. He has left behind an example of what one man can do in advancing knowledge by energy and perseverance.

W. BOYD D AWKINS.

\section{THE LATE CAPTAIN CAMERON.}

CAPTAIN VERNEY LOVETT CAMERON, C.B., R.N., died very suddenly, in his fiftieth year, on March 26 , in consequence of being thrown from his horse while returning from a day's stag-hunting. His name is associated with the most stirring period of modern inland exploration in Africa. In $187 \mathrm{I} \mathrm{Mr.} \mathrm{H.} \mathrm{M.} \mathrm{Stanley}$ met and relieved Livingstone at $\mathrm{Ujiji}$, and on returning to the east coast met the Livingstone relief expedition of the Royal Geographical Society, the leader of which, believing his work to be forestalled, declined to proceed, and broke up his caravan. Lieutenant Cameron had for some time been anxious to explore Africa, and had been one of the unsuccessful applicants for the command of the abortive expedition. On its collapse he submitted proposals for the exploration of the Victoria Nyanza and of east equatorial Africa to the Royal Geographical Society, and in 1872 he was entrusted with a new Livingstone relief expedition, which was to proceed from the east coast, while another expedition, under Lieutenant Grandy, pushed its way up the Congo.

Leaving Bagamoyo early in I 873, Lieutenant Cameron started on his march inland, but was met by the melancholy little group of Living stone's black servants carrying the body of their master. Although the main aim of the expedition was thus frustrated, and all the Europeans of the party were suffering severely from the climate, Cameron determined to push on alone, and not return until he had accomplished some new geographical work. Early in 1874 he reached Lake Tanganyika, surveyed its southern half, and settled the existence of an outflow by the Lukuga; then turning north-eastward, he reached the Lualaba in the Manyema country, and attempted to descend the river. He could not, however, overcome the difficulties in the way, and turning southwards again, made his way by slow stages suffering greatily in health, to the west coast at Benguela. Here he arrived in November 1875 , at the very time when Stanley, more fortunate, was on his march westward from Uganda to finally solve the great problem of the Congo. In 1877 Cameron published his book, "Across Africa," and received various marks of public approval for his services, including his promotion to the rank of Commander, a C.B., the degree of D.C.L. from Oxford, and the gold medal of the Royal Geographical Society. In 1882 he visited the Gold Coast, in company with Sir Richard Burton, on a commercial mission, and during his later years be became more and more deeply interested in various trading companies engaged in the exploitation of Africa. Captain Cameron was respected as an authority on Central African affairs, and took a prominent place, both in this country and in France, in promoting new enterprises.

No. 1275 , voL. 49 ] 